\title{
POLITIK PEMBANGUNAN HUKUM PERJANJIAN INTERNASIONAL TERKAIT STATUS DAN KEDUDUKAN PERJANJIAN INTERNASIONAL DI TINJAU DARI PRAKTIK INDONESIA
}

\author{
Siti Sumartini \\ Universitas Wiralodra Indramayu \\ Jl. Ir. H Juanda KM. 3, Kabupaten Indramayu \\ Email: sitisumartini_unwir@yahoo.co.id
}

\begin{abstract}
International agreements (treaties) is one of the mechanisms in international relations as well as one of the sources of international law. Lack of understanding of what the public understanding of international agreements often giving riseto confuse in ournational legal system. Thereby also on the status and position of international treaties in the practice of Indonesia has not provided clarity about what the system is about to be followed by Indonesia .
\end{abstract}

\section{Keywords : International Treaties, International Law and Municipal Law}

\begin{abstract}
Abstrak
Perjanjian internasional merupakan salah satu mekanisme dalam hubungan internasional serta sebagai salah satu sumber hukum internasional. Kurangnya pemahaman publik terhadap perjanjian internasional sering memberikan resiko kebingungan dalam sistem hukum Negara kita. Demikian juga pada status dan posisi perjanjian internasional dalam praktek Indonesia belum memberikan kejelasan tentang sistem apa yang akan diikuti oleh Indonesia.
\end{abstract}

\section{Kata Kunci: Perjanjian Internasional, Hukum Internasional, Municipal Law}

\section{A. Pendahuluan}

Dalam era globalisasi ini, interaksi dan intensitas hubungan antar negara telah semakin meningkat dan antara lain ditandai pula dengan dicapainya berbagai kesepakatan kerja sama baik yang bersifat bilateral, regional maupun multilateral. Berbagai kesepakatan tersebut lazimnya dituangkan dalam suatu bentuk perjanjian internasional meliputi berbagai bidang termasuk politik, ekonomi, perdagangan, hukum, pertahanan, sosial budaya dan lain sebagainya. ${ }^{1}$ Saling membutuhkan antara bangsa-bangsa dipelbagai bidang kehidupan yang mengakibatkan timbulnya hubungan yang tetap dan terus menerus antara bangsa-bangsa mengakibatkan pula timbulnya kepentingan untuk memelihara dan mengatur hubungan yang demikian, karena hubungan antar negara adalah hubungan yang sifatnya timbal balik, maka dirasakan sangat penting untuk menjaga dan mengatur hubungan yang bermanfaat tersebut karena hal demikian juga merupakan kepentingan bersama. ${ }^{2}$

1 Eddy Pratomo, Hukum Perjanjian Internasional (Pengertian, Status Hukum, Dan Ratifikasi), Alumni, Bandung, 2011, hlm.1

Mochtar Kusumaatmadja, Pengantar Hukum Internasionl, Putra Abardin, Jakarta, 1982, hlm.9 
Hukum internasional modern sebagai suatu sistem hukum yang mengatur hubungan antar negara-negara, lahir dengan kelahiran masyarakat internasional yang didasarkan atas negaranegara nasional. Seorang penulis hukum internasional modern Hingorani telah menggambarkan mengenai pengertian hukum internasional modern sebagai berikut: "It said that consent is the basis of international law obviously, international law is law governing relations among nations which do not recognized any authority superior to them.",

Pada sisi lain perkembangan negara Indonesia dewasa ini dalam era reformasi juga tidak terlepas dari dua aspek yang melingkupinya pertama adalah aspek internal yakni proses demokratisasi yang sedang membawa negara Indonesia kepada bentuk negara demokrasi yang matang (mature) sesuai dengan falsafah bangsa yang dianutnya dan kedua adalah aspek globalisasi sebagai aspek eksternal yang memberikan dampak terhadap kedudukan negara Indonesia didalam sistem masyarakat internasional dan mekanisme hubungan antar negara yang dilakukannya. Dalam hal melaksanakan hubungan luar negeri dewasa ini tidak terlepas dari mekanisme perjanjian internasional. Didalam perkembangan sejarah hukum internasional, perjanjian yang dilakukan antara negara mempunyai peranan yang sangat mendasar, bahkan perjanjian internasional itu sendiri merupakan sumber hukum internasional dan sekaligus sebagai cara bagi semua negara untuk mengembangkan kerjasama yang damai apapun sistem sosial dan konstitusinya. Kemampuan untuk membuat perjanjian internasional adalah merupakan suatu atribut dari negara yang berdaulat. ${ }^{4}$

Akibat dari terjadinya hubungan antar negara tersebut sangat dimungkinkan terjadi benturan antara sistem hukum nasional dengan perjanjian internasional. Sistem hukum yang bereformasi ini telah menekankan aspek konstitutionalitas sehingga memberi batasan kepada kekuasaan negara terhadap rakyatnya, dan sekaligus membatasi kekuasaan negara untuk membuat perjanjian internasional yang selama ini dinikmati sebagai prerogatif Presiden. Konstitusi telah menjadi tolok ukur dalam penyelengaraan negara dan menjadi basis untuk menentukan norma apa yang dapat diterima untuk membatasi kebebasan individu. ${ }^{5}$ Kondisi ini semakin rumit dengan adanya perkembangan eksternal. Selama ini persoalan konstitutionalitas perjanjian internasional tidak pernah dipersoalkan karena secara konvensional perjanjian internasional dipahami hanya sebagai kontrak antar negara dan nyaris tidak berhubungan dengan domain hukum nasional. Secara substansi, pemahaman selama ini perjanjian internasional hanya dimengerti sebagai instrumen yang mengatur hubungan antar negara dan tidak mengatur objek internal negara (Treaty binds on states not in States).

Akibatnya seringkali perjanjian internasional hanya dilihat sebagai urusan Kementerian Luar Negeri. Saat ini, kedua perkembangan diatas telah semakin mengintensifkan interaksi dan interplay antara perjanjian internasional dengan hukum nasional yang ditandai dengan semakin banyaknya persoalan hukum nasional yang ternyata juga diatur oleh perjanjian internasional. Tanpa disadari, perjanjian internasional dapat memuat materi yang mengatur

\footnotetext{
R.C Hingorani, Modern International Law, second edition, Oceana Publications Incorporation, New York, 1984, hlm.15

Sumaryo Suryokusumo, Hukum Perjanjian Internasional, Tatanusa, Jakarta, 2008, hlm. 1\&6

5 Damos Dumoli Agusman, Status Perjanjian Internasional menurut Pandangan Mahkamah Konstitusi RI (Kajian Kritis terhadap Keputusan MK tentang Piagam ASEAN) (Dimuat dalam Buku Peran Hukum dalam Pembangunan di Indonesia), Peringatan Purnabakti Prof. Dr. Etty R. Agoes SH, LL.M, Bandung 2013, hlm. 256-268
} 
kehidupan individu ${ }^{6}$ (seperti dalam penegakan HAM). Penerapan status dan implementasi mengenai perjanjian internasional setiap negara berbeda-beda, terdapat beberapa paham mengenai penerapan hukum internasional dalam ranah hukum nasional setiap negara. Dalam hal ini nampak bahwasannya paham yang dianut oleh sebuah negara juga bergantung pada sistem hukum yang dianut masing-masing negara.

Sejarah mencatat bahwasannya proses mengikatnya aturan perjanjian internasional pada Indonesia telah dikukuhkan dalam berbagai peraturan perundang-undangan nasional seperti yang diamanatkan dalam Pasal 11 UUD 1945 mengenai ratifikasi perjanjian internasional. Hal ini diatur lebih lanjut dalam Surat Presiden No. 2826/HK/ tahun 1960 perihal pembuatan perjanjian-perjanjian dengan negara lain yang kemudian disempurnakan dalam Pasal $10 \mathrm{UU}$ No. 24 tahun 2000 tentang Perjanjian Internasional. Praktik Indonesia mengenai pembuatan perjanjian internasional sebelum lahirnya Undang-Undang No. 24 Tahun 2000 tidak luput dari kerancuan karena semua dokumen sepanjang bersifat lintas negara dan sepanjang yang menjadi pihak adalah Pemerintah Indonesia dianggap sebagai perjanjian internasioal. ${ }^{7}$ Dalam Hukum Tata Negara Indonesia tidak mudah untuk menemukan kaidah hukum yang mengatur tentang status Hukum Internasional dan Perjanjian Internasional dalam Hukum Nasional Republik IndonesiaI. UUD 1945 tidak mencantumkan satu pasal pun yang mengatur status tersebut. ${ }^{8}$ Disamping itu dinamika ketetatanegaraan Indonesia juga telah memberi warna dalam permasalahan perjanjian internasional yang dilakukan oleh Indonesia, dimana pada masa orde lama dan orde baruPresiden bebas menentukan apakah suatu perjanjian internasional perlu dimintakan ataukah tidak dimintakan persetujuan kepada dewan, sementara dewan sendiri juga tidak pernah mempermasalahkannya karena dialatarbelakangai oleh anggapan bahwa persetujuan DPR dalam pasal 11 Undang-Undang 1945 (sebelum amendemen) hanya bersifat fakultatif. Hal inilah yang kemudian telah mendorong diamandemennnya Pasal 11 Undang-Undang Dasar 1945 dengan ditambahkannya ayat 2 dalam pasal tersebut telah menjelaskan bahwasannya dalam perjanjian internasional persetujuan DPR adalah sebagai suatu keharusan.

Sebelum lahirnya undang-undang ini (UU No. 24 Tahun 2000), semua dokumen sepanjang bersifat lintas negara, sepanjang yang menjadi pihak adalah Pemerintah Republik Indonesia, diperlakukan sebagai perjanjian internasional dan disimpan dalam "Treaty Room" Departemen Luar Negeri. Perjanjian yang dibuat Pemerintah RI dengan Organisasi Non Pemerintah (NGO) juga dianggap sebagai perjanjian internasional. Agreement yang dibuat oleh Pertamina and PT Caltex, PT Stanvac and PT Shell juga pernah dianggap sebagai perjanjian internasionaldan bahkan diratifikasi melalui Undang-Undang No. 1 Tahun 1996. ${ }^{9}$ Disamping itu dengan masuknya Indonesia menjadi state party dalam perjanjian internasional

\footnotetext{
Idem

Damos Dumoli Agusman, Hukum Perjanjian Internasional Kajian Teori dan Praktik Indonesia, Refika Aditama, Bandung, 2010, hlm. 32

8 http://damosdumoli.blogspot.com/Perjanjian Internasional, Teori, Praktek dan Statusnya, diunduh ada tanggal 27 Oktober 2014, pukul 13,45 WIB.

9 Damos Dumoli Agusman, Apakah Perjanjian Internasional itu? Beberapa Perkembangan Teori dan Praktek Di IndonesiaTentang Hukum Perjanjian Internasional (Refleksi Dinamika Hukum Rangkaian Pemikiran Dalam Dekade Terakhir), Alumni, Bandung, 2008, hlm.115
} 
mengenai perdagangan (TRIPs/TRIMs dan WTO), hal ini juga mempengaruhi hukum hukum nasional kita. Demikian juga dalam bidang pembangunan HAM yang tidak dapat diabaikan bahwa peranan perjanjian internasional sangat signifikan terhadap status dan kedudukan ratifikasi HAM dalam hukum tata negara Indonesia. (spserti belum adanya peraturan perundangan nasional yang mengatur mengenai anti penyiksaan, setelah Indonesia meratifikasi Convention against Torture and Other Cruel Inhuman and Degrading Treatment or Punishments (CAT) melalui Undang-Undang No.5 Tahun 1998).

Persoalan lain yang ikut memberikan polemik pada dinamika hukum ketatanegaraan terkait masalah perjanjian internasional adalah dengan dijudicial reviewnya Undang-Undang No.38 Tahun 2008 Tentang Pengesahan ASEAN Charter (Piagam Asean) oleh Makamah Konstitusi. ${ }^{10}$ Mahkamah Konstitusi dalam hal ini ${ }^{11}$ beranggapan bahwasannya UndangUndang No.38 Tahun 2008 ini kedudukannya sama dengan undang-undang lainnya sehingga bisa "diuji materiilkan." Penulis sendiriberasumsi bahwasannya undang-undang tersebut hanya bersifat implementatif pengesahan dari ASEAN Charter. Demikan juga mengenai undang-undang No. 24 Tahun 2004 yang secara teknis mengatur perjanjian internasional, namun jika kita melihat dalam Pasal 10 undang-undang tersebut yang mengatur masalah materi atau isi substansi perjanjian internasional itu akan kita temukan (pada huruf f) bahwa perjanjian internasional yang memuat materi pinjaman/hibah luar negeri harus dilakukan dengan melalaui mekanisme pengesahan (ratifikasi) artinya perjanjian tersebut governed by internasional law, namun dalam parkteknya banyak pinjaman (loan agreement) diatur dengan menggunakan rezim hukum perdata internasional yang dalam mekanismenya yakni menggunakan governed by other than law atau yang sering dipahami juga sebagai choice of law dalam aspek hukum perdata internasional.

Hal-hal yang dijelaskan diatas tersebut adalah sebagian dari problem terkait status dan kedudukan hukum perjanjian internasional dalam ranah hukum nasional. Kemudian persoalan mengenai begaimanakah praktek Indonesia memandang hukum perjanjian internasional dalam bingkai hukum nasionalnya juga menjadi persoalan tersendiri.Demikian pula dengan perjanjian-perjanjian internasional lainnya yang telah dijalankan Indonesia selama ini masih banyak ketidaksesuaian antara aturan (dalam hal ini regulasi) dengan praktik dilapangan. Ketidakjelasan mengenai status dan kedudukan perjanjian internasional yang dilakukan oleh negara kita selama ini tidak terlepas dari kurangnya pengaturan yang lebih jelas dan rinci mengenai perjanjian internasional di dalam perundang-undangan negara kita. Dimana hal ini akan saling bertali temali dengan kebijakan hukum (politik hukum) yang berlaku di negara kita

\footnotetext{
${ }^{10} \mathrm{http} / / / w w w . s l i d e s h a r e . n e t / a t s t u r d y /$ politik-hukum-perjanjian-internasional-indonesia diakses pada tanggal 15 oktober 2014;pukul 18.01

11 penulis mencermati bahwa tindakan Mahkamah Konstitusi dalam hal menjudicial review Undang-Undang No.38 Tahun 2008 adalah tindakan yng mencerminkan sikap dualisme terhadap kedudukan hukum internasional (mengenai perjanjian internasional) dalam perspektif hukum nasional Indonesia,karena menganggap status dan kedudukan undang-undang no. 38 tahun 2008 tersebut sama dengan peraturan perundang-undangan lainnya.
} 


\section{B. Rumusan Permasalahan}

Berdasarkan latar belakang tersebut maka dapat dirumuskan permasalahan hukum sebagai berikut :

1. Bagaimanakah status dan kedudukan perjanjian internasional yang dilaksanakan oleh Indonesia terkait pengaturannya dalam tata regulasi nasional?

2. Bagaimanakah peran politik hukum terkait pengaturan perjanjian internasional yang dibuat oleh Indonesia selama ini?

\section{Pembahasan}

Hukum Internasional pada umumnya diartikan sebagai himpunan peraturan-peraturan dan ketentuan-ketentuan yang mengikat serta mengatur hubungan antara negara-negara dan subyek-subyek hukum lainnya dalam kehidupan masyarakat internasional.

Hukum internasional dalam perkembangannya dewasa ini telah mengalami berbagai perubahan bentuk (metamorfosis). Perkembangan dan perubahan bentuk ini tidak terlepas dari perkembangan dan perubahan bentuk dari struktur masyarakat internasional itu sendiri. Dalam kerangka hubungan antar negara hukum internasional dipahami atau dipandang sebagai "a system of agreements between international actors" yakni negara-negara yang merumuskan bagaimana hubungan diantara negara-negara tersebut dapat dilaksanakan secara kondusif, atau dengan rumusan lain, bahwa hukum internasional dikatakan "as a body of rules that countries feel an obligation to obey in their".

Indonesia sebagai bagian dari komunitas internasional, tentunya tidak luput dari pergaulan internasional. hal ini dipertegas dengan Pembukaan Undang-Undang Dasar 1945, salah satu tujuan Pemerintah NKRI adalah adalah ikut melaksanakan ketertiban dunia yang berdasarkan kemerdekaan, perdamaian abadi dan keadilan sosial, selanjutnya negara Indonesia sebagai negara yang merdeka dan berdaulat penuh pelaksanaan hubungan luar negeri didasarkan pada asas kesamaan derajat, saling menghormati, saling menguntungkan dan saling tidak mencampuri urusan dalam negeri masing-masing negara.

Sebenarnya yang menjadi pelaku atau yang menjalankan peran di dalam hubunganhubungan menurut tata tertib hukum itu adalah manusia, begitupula halnya dengan hukum internasional, telah kita ketahui bahwa subyek hukum internasional adalah negara, namun negara-negara itupun tidak dapat sebagai negara an sich menjalankan tindakan-tindakan apapun didalam tata tertib hukum internasional, sebab negara hanyalah merupakan pengertian teknis saja, tidak dapat bergerak atau berdiri sendiri, melainkan lewat manusia-manusia yang ada didalam organisasi yang bernama negara itu dimana oleh negara tersebut diberi wewenang untuk berbuat atau tidak berbuat. ${ }^{12}$ Konsepsi kedaulatan baik yang dijelaskan oleh Bodin ataupun Austin dewasa ini sudah tidak dapat dilaksanakan secara konsekuen, karena aspek kedaulatan yang disodorkan bersifat intern saja hanya dimaksudkan untuk mengatur

12 Ali Sastroamidjojo, Pengantar Hukum Internasional, Bratara, Bandung, 1992, hlm. 52-53 
masyarakat didalam suatu negara, sedangkan kenyataan sekarang ini negara sudah merupakan bagian dari masyarakat internasional, dimana hubungan antar negara merupakan kebutuhan yang terus berkembang sedemikian luas. ${ }^{13}$ Disamping itu kemajuan teknologi dan komunikasi mengakibatkan aktivitas ekonomi (globalisasi) tidak lagi terkungkung oleh batas-batas negara.

Kekuatan teori-teori mengenai prinsip kedaulatan dan persamaan negara mulai berkurang. Setiap negara yang merdeka adalah negara yang berdaulat. Mereka bebas membuat kebijakan-kebijakan guna mengatur sistem ekonomi, poltik, hukum dan lain-lain dalam negerinya, namun demikian perkembangan dewasa ini mengalami pergeseran makna, apa yang sebelumnya menjadi kewenangan atau tindakan berdaulat penuh suatu negara menjadi berkurang pengertiannya manakala kepentingan negara lain terganggu. Negaranegara mematuhi hukum internasional karena kepatuhan tersebut di perlukan untuk mengatur hubungan antara satu dengan yang lain dan untuk melindungi kepentingan negara itu sendiri. Negara tersebut patuh karena merupakan kepentingan mereka untuk berbuat demikian. ${ }^{14}$

Fenomena diatas sebagian besar diwarnai pula oleh semakin meningkatnya saling ketergantungan (interdependensi) ekonomi dunia. Ketergantungan ini disebabkan karena bervariasinya sumber-sumber alam atau faktor-faktor dominan lainnya. Seperti; jumlah penduduk, teknologi, atau ekonomi antara satu negara dengan negara lainnya. ${ }^{15}$ Pengaturan hubungan antar negara dewasa ini lebih dalam mekanisme perjanjian internasional.Menurut ajaran dari Anzilotti, perjanjian internasional mengikat berdasarkan prinsip "pacta sunt servanda" (article 26 Vienna Convention 1969). Prinsip ini juga sesuai dengan Deklarasi London tahun 1871 yang menyatakan bahwa negara-negara mengakui prinsip hukum internasional yang menetapkan bahwa negara tidak dapat membedakan diri dari ikatan perjanjian internasional atau mengubah ketentuannya tanpa persetujuan pihak lawan berjanji melalui saling pengertian yang bersahabat. Dan dalam hal terdapat suatu perjanjian yang mengatur persoalan yang dipersengketakan, keputusan Mahkamah Internasional akan didasarkan pada ketentuan-ketentuan dalam perjanjian tersebut. Perjanjian internasional menempati posisi yang sama pentingnya di dalam bidang hukum internasional sebagaimana perundangan-undangan dalam system hukum nasional. ${ }^{16}$

Bagaimana halnya dengan negara Indonesia menyangkut kedudukan hukum internasional dalam sistem hukum nasionalnya, untuk negara Indonesia masih terdapat ketidak jelasan mengenai pengertian dan status perjanjian internasional, baik pada tataran regulasi ataupun praktik Indonesia selama ini dalam menyikapi definisi mengenai perjanjian internasional, belum adanya kesamaan pandangan tentang apa yang dimaksud dengan perjanjian internasional itu sendiri. Persoalan yuridis yang selalu mewarnai praktik Indonesia selama ini

\footnotetext{
${ }^{13}$ Eddy Purnama, Negara Kedaulatan Rakyat, Analisis Terhadap Sistemm Pemerintahan Indonesia dan Perbandingannya dengan Negara-Negara Lain, Nusamedia, Bandung, 2007, hlm. 30

14 Mahendra Putra Kurnia, Ketika Hukum Berhadapan Dengan Globalisasi, Universitas Brawijaya Press, Malang, 2011, hlm. 15

15 Huala Adolf, Hukum Ekonomi Internasional Suatu Pengantar, Keni Media, Bandung, 2010, hlm. 2

16 Sumaryo Suryokusumo, op.cit hlm. 29
} 
adalah belum adanya perbedaan yang tegas antara perjanjian internasional dengan kontrak internasional. ${ }^{17}$

Bentuk perjanjian lintas batas (transnational) dalam praktiknya memiliki dua (2) jenis yang berbeda, yakni perjanjian internasional yang tunduk pada hukum publik dan persetujuan-persetujuan internasional lainnya yang tunduk pada sistem hukum perdata internasional (ie; kontrak internasional). Sejalan dengan hal ini Adanya bentuk persetujuan internasional lainnya disamping perjanjian internasional tersebut telah merupakan kenyataan yang tercatat dalam sejarah dan sudah sejak lama perjanjian internasional telah menjadi kebiasaan bagi negarawan-negarawan untuk menggunakan aturan-aturan hukum yang mengatur hubungan hukum yang bersifat kontraktual baik antara individu-individu secara tersendiri maupun yang mengatur hubungan antar negara. Kondisi tersebut di perkuat oleh penjelasan dari seorang ahli hukum internasional Wolfgang Friedmanyang menjelaskan bahwa disamping adanya perjanjian internasional yang disebut "treaty" ada beberapa persetujuan internasional yang keberadaannya melengkapi treaty tersebut. Dijelaskan bahwa hal tersebut sebagaimana:

"a new type of international transaction somewhere between the traditional spheres of public and private international law has gained increasing acceptance, it is best described as "international agreements", we must accept these international agreements other than treaties as additional source of public international law, because they concern and affect public international relations."

Pada sisi lain Indonesia sendiri masih belum meposiskan dirinya secara tegas apakah menganut paham monisme ataukah dualisme menyakut status dan kedudukan perjanjian internasional dengan hubungan hukum nasional nya.

Secara teori terdapat dua mazhab mengenai pemberlakuan perjanjian internasional dalam hukum nasional yang kita telah mengenalnya dalam studi hukum internasional yakni aliran monisme dan mazhab dualisme, secara konstitusi atau legelasi Indonesia tidak pernah menyatakan dengan tegas apakah Indonesia menganut monisme (inkorporasi/penggabungan) ataukah menganut dualisme (yang memerlukan transformasi/penjelamaan) ataukah bentuk tersendiri, sehingga dengan tidak adanya ketegasan tersebut praktek Indonesia dalam memberlakukan perjanjian internasional kedalam hukum nasionalnya sering tidak konsisten, seperti contoh; seperti UNCLOS (United Nations Convention on The Law of The Seas) 1982 yang telah diratifikasi Indonesia melalui Undang-Undang No. 17 Tahun 1985 tetapi tetap membutuhkan Undang-Undang No. 6 Tahun 1996 tentang Perairan Indonesia, hal ini menunjukkan Indonesia mengacu pada mazhab dualisme, namun dilain pihak terdapat pula perjanjian internasional yang diratifikasi dan dijadikan dasar hukum untuk implementasi, seperti Konvensi Wina 1961 dan 1963 (Vienna Convention 1961 dan 1963) tentang Hubungan

17 Ibid, hlm.254-255 
Diplomatik dan Konsuler yang diratifikasi dengan Undang-Undang No.1 Tahun1982, ${ }^{18}$ bahwasannya dalam hal ini Indonesia telah mengacu pada mazhab monisme.

Ketidakjelasan Indonesia menyangkut praktik Indonesia selama ini dalam memposisikan perjanjian internasional diantara hukum internasional dengan hukum nasional nya perlu segera dibenahi dengan menggunakan politik hukum yang memadai, dimana dipahami bahwasannya politik hukum bahwa politik hukum dalam persepktif akademis tidak hanya berbicara sebatas pengertian mengenai politik hukum yang sedang berlaku atau secara an sich namun juga mengkritisi produk-produk hukum yang telah dibentuk, dengan demikian politik hukum menganut prinsip double movement, yakni selain sebagai suatu kerangka pikir yang merumuskan kebijakan dalam bidang hukum (legal policy) oleh negara-negara yang berwenang, ia juga dipakai untuk mengkritisi produk-produk hukum yang telah diundangkan berdasarkan legal policy diatas. ${ }^{19}$ Sementara Sementera Bellefroid seorang ahli hukum berkebangsaan Perancis mengatakan bahwa pada dasarnya politik hukum itu mencakup halhal untuk menyelidiki perubahan-perubahan apakah yang harus diadakan pada hukum yang ada sekarang, supaya dapat memenuhi syarat-syarat baru dari kehidupan kemasyarakatan, selain itu politik hukum adalah menelaah perubahan ketentuan hukum yang berlaku dengan memilih dan menentukan ketentuan hukum tentang tujuan beserta cara dan sarananya untuk dapat mencapai tujuan tersebut dalam memenuhi perubahan kehidupan masyarakat yang dicita-citakan. ${ }^{20}$

\section{Kesimpulan}

Bahwasannya status dan kedudukan perjanjian internasional menyangkut praktik Indonesia selama ini belumm menampakkan kejelasan mengenai sistem apa yang akan digunakan dalam kaitannya dengan prosedur internal yakni domain hukum nasional kita, disisi lain pengertian publik (masyarakat) bahkan juga sebagian pengambil keputusan dalam tataran birokrat kerap kali mengalami distorsi (salah paham) mengenai perjanjian internasional itu sendiri. Oleh karenanya para pemangku kepentingan (Pemerintah) terutama pihak-pihak yang terkait dengan persoalan tersebut seyogyanya segera merespon agar kesalahan dan kebingungan mengenai status dan kedudukan perjanjian internasional menjadi tidak berlarut-berlarut. Tentunya politik hukum adalah sarana yang tepat untuk bisa memposiikan secara jelas dan mengarahkan kemana perjanjian internasional ini akan dibawa.

\section{Daftar Pustaka}

\section{Buku}

\footnotetext{
18 Damos Dumoli Agusman (ToR DEPLU Mengenai Studi Tentang Sistem Hukum Suatu Negara Terkait Dengan Proses Pengesahan Danpemberlakuan Perjanjian Internasional Serta Pengolahan Naskah Perjanjian Internasional Oleh Suatu Negara Dan Organisasi Internasional

19 Ibid, hlm 44-45

20 Abdul Latif dan Hasbi Ali, PolitikHukum, Sinar Grafika, Jakarta, 2011, hlm. 11
} 
Abdul Latif dan Hasbi Ali, PolitikHukum, SinarGrafika, Jakarta, 2011;

Ali Sastroamidjojo, Pengantar Hukum Internasional, Bratara, Bandung, 1992;

Damos Dumoli Agusman, Hukum Perjanjian Internasional Kajian Teori dan Praktik Indonesia, Refika Aditama, Bandung, 2010;

, Apakah Perjanjian Internasional itu? Beberapa Perkembangan Teori dan Praktek Di Indonesia Tentang Hukum Perjanjian Internasional (Refleksi Dinamika Hukum Rangkaian Pemikiran Dalam Dekade Terakhir), Alumni, Bandung, 2008;

, (ToR DEPLU Mengenai Studi Tentang Sistem Hukum Suatu Negara Terkait Dengan Proses Pengesahan dan Pemberlakuan Perjanjian Internasional Serta Pengolahan Naskah Perjanjian Internasional Oleh Suatu Negara Dan Organisasi Internasional)

, Status Perjanjian Internasional menurut Pandangan Mahkamah Konstitusi RI (Kajian Kritis terhadap Keputusan MK tentang Piagam ASEAN) (Dimuat dalam Buku Peran Hukum dalam Pembangunan di Indonesia), Peringatan Purnabakti Prof. Dr. Etty R. Agoes SH, LL.M, Bandung 2013

Eddy Pratomo, Hukum Perjanjian Internasional Pengertian, Status Hukum, Dan Ratifikasi, Alumni, Bandung, 2011;

Eddy Purnama, Negara Kedaulatan Rakyat, Analisis Terhadap Sistemm Pemerintahan Indonesia dan Perbandingannya dengan Negara-Negara Lain, Nusamedia, Bandung, 2007;

, Hukum Ekonomi Internasional Suatu Pengantar, Keni Media, Bandung, 2010

Mahendra Putra Kurnia, Ketika Hukum Berhadapan Dengan Globalisasi, Universitas Brawijaya Press, Malang, 2011;

Mochtar Kusumaatmadja, Pengantar Hukum Internasionl, Putra Abardin, Jakarta, 1982

R. C. Hingorani, Modern International Law, second edition, Oceana Publications Incorporation, New York, 1984

Sumaryo Suryokusumo, Hukum Perjanjian Internasional, Tatanusa, Jakarta, 2008

\section{Internet}

http://damosdumoli.blogspot.com/Perjanjian Internasional, Teori, Praktek dan Statusnya, diunduh ada tanggal 27 Oktober 2014, pukul 13,45 WIB

http://www.slideshare.net/atsturdy/politik-hukum-perjanjian-internasional-indonesia, diakses pada tanggal 15 oktober 2014; pukul 18.01 